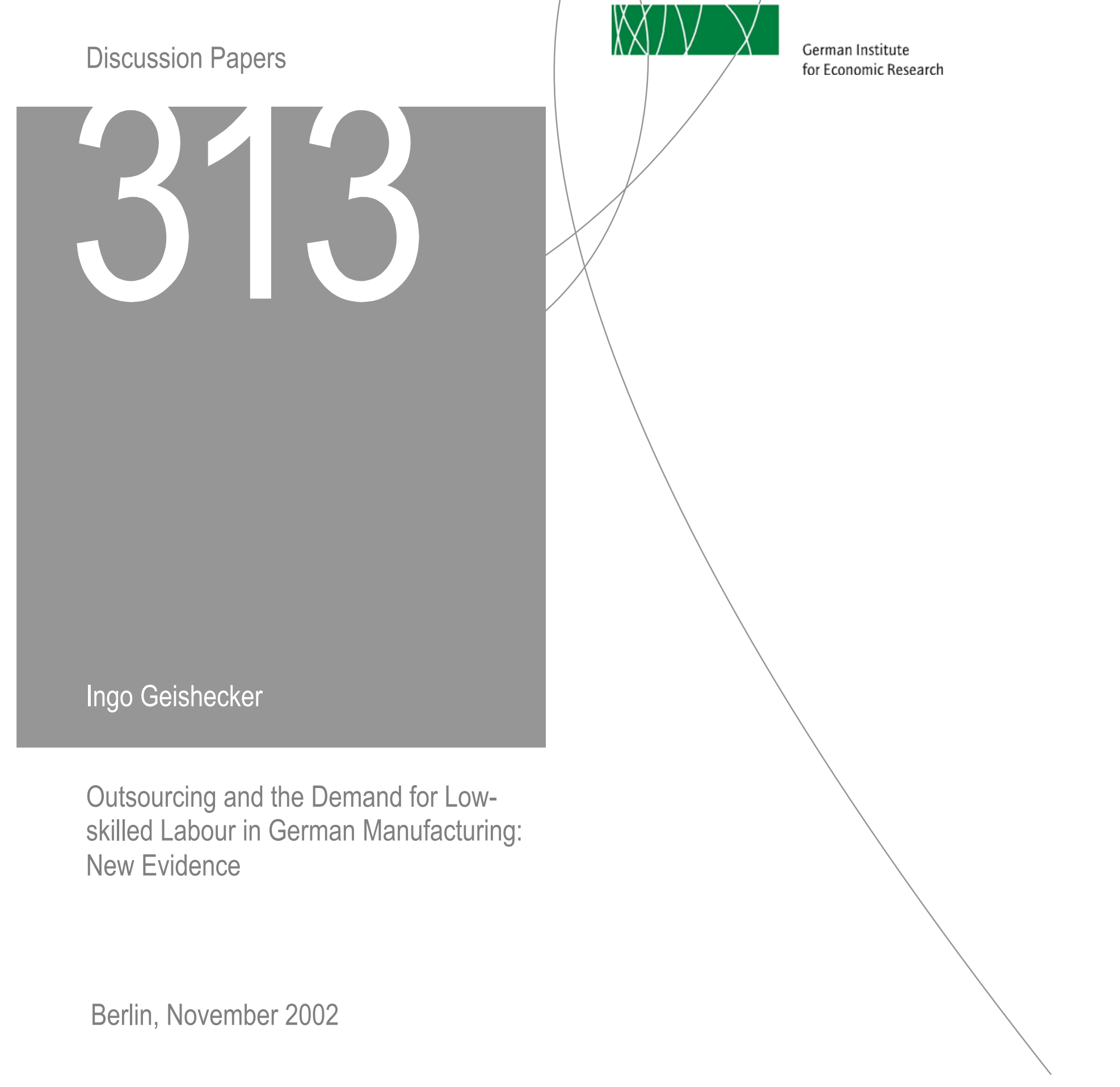


Opinions expressed in this paper are those of the author and do not necessarily reflect views of the Institute.

\section{DIW Berlin}

\section{German Institute}

for Economic Research

Königin-Luise-Str. 5

14195 Berlin,

Germany

Phone +49-30-897 89-0

Fax +49-30-897 89-200

www.diw.de

ISSN 1619-4535 


\title{
Outsourcing and the Demand for Low-skilled Labour in German Manufacturing: New Evidence*
}

\author{
Ingo Geishecker \\ DIW-Berlin
}

October 2002

\begin{abstract}
This paper analyses how international outsourcing has affected the relative demand for low skilled workers in Germany during the 1990s. In contrast to previous empirical work, the single elements of the input-output-matrix are used to disentangle international outsourcing and trade in final goods more accurately. The main finding is that during the 1990s international outsourcing had a significant negative impact on the relative demand for low-skilled workers, explaining between $19 \%$ and $24 \%$ of the overall decline in the relative demand for low-skilled labour.
\end{abstract}

Keywords: international trade, outsourcing, skill-bias, labour demand JEL classification: F20, J31, J23

\section{Corresponding Address:}

Ingo Geishecker, DIW Berlin, International Economics

Koenigin-Luise-Str.5, D-14191, Berlin Germany

Tel: +49-30-89789-610 Fax: +49-30-89789-108 E-mail: igeishecker@diw.de

*The author would like to thank: J. Bitzer (DIW Berlin), H. Brücker (DIW Berlin), P. R. Gregory (University of Houston), J. Haisken De New (DIW Berlin), M. Pannenberg (DIW Berlin), A. Stephan (DIW Berlin) and J. Wolters (Free University Berlin) for their very helpful comments. 


\section{Introduction}

This paper is concerned with the impact of international outsourcing on the relative demand for low-skilled workers in Germany during the 1990s. Previous empirical work on Germany for the 1980s has in general rejected the relevance of low-skilled labour saving international outsourcing, thereby contradicting abundant anecdotical evidence. The paper contributes to the existing literature in providing the, to the best knowledge of the author, first empirical assessment of the impact of international outsourcing on the demand for low-skilled workers in German manufacturing during the 1990s.

It is a well established fact that over the past decades a substantial skill upgrading of employment has occurred in Germany [see Reinberg and Hummel (2002)]. As can be seen in table 1, employment of the low-skilled decreased sharply by on average $3.6 \%$ per year between 1975 and 1990 and continued to fall all through the 1990s by on average $1.3 \%$ per year. In contrast employment of the high- and medium skilled increased by on average $4.3 \%$ and $2.1 \%$ per year between 1975 and 1990 and continued to rise during the 1990s with average yearly growth rates of $3.6 \%$ and $0.2 \%$. At the same time relative wages of low-skilled workers remained very stable [see Fitzenberger (1999) and Christensen and Schimmelpfennig (1998)].

On the basis of aggregate employment and wage data for production and nonproduction workers, the process of skill upgrading can by analysed in more detail. ${ }^{1}$ For the whole manufacturing industry ${ }^{2}$, the cost share of low-skilled workers in the total wage bill decreased by 23 percentage points between 1991 and 2000. Decomposing this overall change shows that only 2 percentage points of it can be attributed to decreased relative wages but 21 percentage points to decreased relative employment of low-skilled workers. ${ }^{3}$ Thus the findings by Fitzenberger et al. (2001) and

\footnotetext{
${ }^{1}$ The distinction between low- and high-skilled workers based on the broad categories production- and non-production work may be not clear cut. However this can be justified since the correlation between high-skilled and non-production workers is very high.

${ }^{2}$ Excluding the industries: oil refining, printing and publishing, recycling

${ }^{3}$ The formula for the decomposition is:

$$
\Delta\left(\frac{w^{L S} \times L^{L S}}{w^{H S} \times L^{H S}}\right)=\Delta\left(\frac{w^{L S}}{w^{H S}}\right) \times \frac{\frac{L_{t}^{L S}}{L_{t}^{H S}}+\frac{L_{t-n}^{L S}}{L_{t-n}^{H S}}}{2}+\Delta\left(\frac{L^{L S}}{L^{H S}}\right) \times \frac{\frac{w_{t}^{L S}}{w_{t}^{H S}}+\frac{w_{t-n}^{L S}}{w_{t-n}^{H S}}}{2}
$$

With $w^{L S, H S}$ denoting the wage for low- and high skilled workers and $L^{L S, H S}$ the employment of lowand high-skilled workers.
} 
Reinberg and Hummel (2002) that are derived from micro data are confirmed.

An important detail is that most of the observed skill upgrading occurred within industries. Using micro data from the German Socio-Economic Panel study, Schimmelpfennig (1998) reports that while the share of high-skilled labour in total employment increased by 6.5 percentage points between 1984/86 and 1994/96, around 5.5 percentage points of this change can be attributed to skill upgrading within industries. ${ }^{4}$ These findings for Germany are in line with empirical evidence on skill upgrading during the 1980s for many OECD-countries [see Berman, Bound and Machin (1998)].

This paper's calculations for the more recent period 1991 to 2000, based on two-digit industry data, show that the overall change in the relative employment of high-skilled workers in the manufacturing industry was +3.2 percentage points, of which +3.9 percentage points can be attributed to within-industry skill upgrading while -0.7 percentage points can be attributed to skill upgrading across industries. Thus there is evidence for a substantial skill upgrading within industries which to a small extent was compensated by a shift towards industries with lower skill intensity. ${ }^{5}$

An important question immediately arises: what is the the driving force behind the observed skill upgrading in manufacturing? In the literature, two explanatory strands have been discussed. One focuses on increased international trade and the other on skill-biased technological change as the main reason for skill upgrading. However, the fact that most skill upgrading occurs within and not across industries has led many authors [e.g. Berman, Bound and Griliches (1994) and Berman et al. (1998)] to conclude that skill-biased technological change rather than international trade is the driving force behind the negative demand shift for low-skilled labour.

It may, however, be misleading to focus solely on skill-biased technological change. First, skill upgrading within industry does not necessarily violate the predictions of standard trade theory if rigid wages are assumed. A lack of wage flexibility prevents the substitution of low-skilled workers, who are then driven out of

${ }^{4}$ Schimmelpfennig (1998) uses data for broad categories of the primary, secondary and tertiary sector.

${ }^{5}$ Note that low-skilled relative employment is now expressed as the share in total employment:

$$
\Delta S^{L S}=\sum_{i} \Delta S_{i}^{L S} \times \bar{E}_{i}+\sum_{i} \Delta E_{i} \times \bar{S}_{i}^{L S}
$$

with $\Delta S^{L S}=\Delta\left(\frac{L^{L S}}{E}\right)$ denoting the overall change in the share of low-skilled labour $\left(L^{L S}\right)$ in total employment $(E)$. 
the market. Second, while standard trade theory mainly focuses on trade with final goods, the analysis of trade with intermediate goods or international outsourcing may yield quite different results, as this paper shows.

Section II discusses the evolvement of international outsourcing in German manufacturing industries. Section III introduces some previous empirical work mainly on the 1980's. In the following section the empirical model is developed. Section V presents the empirical findings and section VI summarises and draws some conclusions.

\section{International Outsourcing}

A theoretical model showing how international outsourcing can affect the relative demand for low-skilled labour within industries has been developed in Feenstra and Hanson (1996). Their model rests on the assumption of different relative factor prices for low- and high-skilled labour in two regions (North and South). The North is assumed to have a lower relative wage for high-skilled labour and thus an absolute cost advantage in the production of skill-intensive intermediate goods. According to the model, capital growth or Hicks-neutral technological progress in the South relative to the North results in a cost advantage of the South in production stages with a higher skill intensity in which the North initially had a cost advantage. Hence the North specialises in increasingly skill-intensive production stages, which leads to decreased relative demand for low-skilled labour.

It should be stressed, however, that the above model only assumes one final goods sector. Applying the model to a whole economy with many sectors abstracts from the possibility of factor movements between sectors, which is only plausible in the short run.

International outsourcing accompanied by trade with intermediate goods has become increasingly important over the past decades. This reflects an

"[...] increasing interconnectedness of production processes in a vertical trading chain that stretches across many countries, with each country specialising in particular stages of a good's production sequence" [Hummels, Ishii and Yi (2001), p. 76].

Anecdotal evidence on firms shifting production stages abroad by subcontracting legally independent suppliers or establishing foreign production sites is manifold. However measuring this process of international outsourcing presents a challenge. 
In general two approaches to measure international outsourcing activities have been pursued in the literature. Authors such as Yeats (1998) seek to measure international outsourcing by directly quantifying trade with intermediate goods, assessing the intermediate character of the traded goods on the basis of disaggregated goods classifications. Imported parts and components are assumed to be intermediate goods imports of the respective broader industry that produces such parts and components. This procedure abstracts from the possibility that parts and components from one industry can be also used by other industries or by final consumers which may bias the measurement outcome.

Other authors such as Campa and Goldberg (1997) and Feenstra and Hanson (1999) quantify international outsourcing by combining input coefficients found in input-output tables and trade data. The estimated value of imported intermediate inputs of an industry thereby largely depends on whether one applies a narrow or wide definition of international outsourcing. Campa and Goldberg (1997) and others assume that the total sum of imported intermediate goods in each industry represents a reasonable indicator for outsourcing. But following Feenstra and Hanson (1999) this "definition" seems too broad.

Outsourcing at the industry level should be understood as the result of a makeor-buy decision. The decision of a domestic car producer, for instance, to buy steel or car tyres from a foreign supplier is therefore clearly not related to outsourcing, since the car producer just does not have the opportunity to make steel or tyres himself. Of course employment in the domestic steel or rubber industry may be affected adversely by this decision but this is due to import competition with final goods and not due to international outsourcing. If one instead focuses on the imported intermediate goods for each industry from the same industry abroad, represented by the main diagonal in the input-output matrix, the effects of trade in final goods and outsourcing can be more accurately separated. However depending on the aggregational level, the range of products that an industry can produce varies. Accordingly, the more highly aggregated the industries are, the broader the definition of international outsourcing becomes. In this paper international outsourcing is defined as the shift of a two-digit industry's core activities abroad. The volume of international outsourcing at the industry level is approximated by the value of the industry's imported intermediate inputs as a share of the sum of domestic and imported inputs within the same two-digit industry:

$$
\text { Outs } s_{i t}=\frac{I m p_{i t}}{I m p_{i t}+\text { Dom }_{i t}}
$$


with $I m p_{i t}$ denoting imported intermediate inputs and $D o m_{i t}$ domestic intermediate inputs of industry $i$ at the time t. Both the value of imported and domestic intermediate inputs can be directly obtained from the main diagonal of input-output tables which for Germany are differentiated with respect to foreign and domestic inputs.

Table 2 shows a substantial increase of 10 percentage points in the share of imported intermediates inputs for the whole manufacturing industry. However it also becomes clear that the importance and growth of international outsourcing varies considerably between industries. In industries such as the manufacturing of wearing apparel or the office machinery and computer industry, international outsourcing has become highly relevant, with the share of imported intermediate inputs rising by 31 and 44 percentage points between 1991 and 2000 and reaching levels of $93 \%$ and $86 \%$ respectively. In other industries such as the manufacturing of wood and wood products or the publishing and printing industry, international outsourcing is only of low importance and has remained negligible all through the 1990s.

\section{Previous Empirical Research}

Feenstra and Hanson (1996) provide one of the first empirical assessments of the impact of international outsourcing on the relative demand for low-skilled workers. In their study on the United States they approximate international outsourcing by the share of imports from a particular industry abroad in total domestic demand for that industry's products. Thus, outsourcing is actually measured as import penetration. Their empirical model is based on a translog cost function with capital as quasi fixed input. From this cost function, a cost share equation for non-production workers is derived. In order to assess the impact of outsourcing, Feenstra and Hanson extend the cost share equation to include the calculated industry's import penetration ratio. Following this procedure, the authors report that approximately $15 \%$ to $33 \%$ of the increase of the cost share of non-production labour over the period 1979-1987 can be explained by international outsourcing. In a follow-up study Feenstra and Hanson (1999) apply a more accurate definition of international outsourcing by focusing on imported intermediate inputs of an industry from the same industry abroad. According to this study international outsourcing can explain between $11 \%$ and $15 \%$ of the observed decline in the cost share of production labour 
in U.S. manufacturing between 1979 and 1990.

A similar study was undertaken by Anderton and Brenton (1999) for the UK. They estimate the impact of outsourcing for a panel of eleven disaggregated textile and mechanical engineering industries. In contrast to Feenstra and Hanson (1996), they do, however, distinguish between imports from low- and high-wage countries. As might be expected, only the coefficient of import penetration from low-wage countries is statistically significant ${ }^{6}$. Furthermore, the impact differs between high-skill-intensive mechanical engineering and the low-skill-intensive textiles industry. While the coefficient of the import penetration variable is, in general, not statistically significant for the mechanical engineering industries, in the textiles industry up to $40 \%$ of the observed rise in the cost share and up to $33 \%$ of the rise in the employment share of skilled workers between 1970 and 1983 can be explained by import penetration from low-wage countries.

Diehl (1999) provides some empirical evidence for the impact of international outsourcing on German manufacturing industries between 1978 and 1990. He uses an ad hoc model for relative labour demand, as well as a well-specified empirical model that is also based on a translog cost function. In contrast to Feenstra and Hanson (1996) and Anderton and Brenton (1999), Diehl uses relative import prices instead of import quantities. While his model contains capital as a quasi fixed input reflecting adjustment costs, to allow capital to differ from its long run equilibrium, imported and domestic imports are implicitly assumed always to be at their longrun equilibrium. To calculate the prices for domestic and imported inputs for each industry, Diehl uses sectoral data for domestic producer and import prices, weighted with the respective foreign and domestic industries share in total inputs. These weights can be obtained from the biannual input-output tables, which distinguish between imported and domestic inputs. Diehl (1999) uses constant weights from the input-output table for 1978. This results, in all probability, in an overestimation of imported input prices. Consider the case of a decline in the price of imported relative to domestic inputs ${ }^{7}$. A further problem with the above approach is the rather broad definition of international outsourcing. As highlighted in section II, when dealing with the relative demand for low-skilled workers, one should focus on

\footnotetext{
${ }^{6}$ Low-skill activities are typically outsourced to low-wage countries

${ }^{7}$ As foreign inputs become relatively cheaper, a substitution towards these inputs should occur, increasing the share of the respective foreign inputs in total inputs and thus pushing down the average relative input price. However holding the weights constant underestimates the actual impact of the initial decline in the relative input price.
} 
the imported intermediate inputs from the same industry abroad, thus applying a narrower definition of international outsourcing.

Diehl (1999) finds that international outsourcing has only a weak impact on the skill structure of employment in German manufacturing. In 16 out of 28 industries, the coefficient of the price variable for imported intermediate inputs is statistically insignificant, implying a substitution elasticity of just one between imported inputs and production workers. Furthermore, the elasticity of substitution between nonproduction workers and imported intermediate inputs is not significantly lower than that of production workers. In addition, the coefficient of the imported input price is statistically significant and negative in 12 out of 28 industries, implying an even lower elasticity of substitution between production labour and imported intermediate inputs. Thus no empirical evidence exists for a shift in the relative demand for production (low-skilled) workers due to international outsourcing.

Diehl (1999) compares his findings with those of Anderton and Brenton (1999) by using import penetration ratios as a proxy for international outsourcing. In general, this variable performs somewhat better than the price variable. Empirical evidence for the impact of international outsourcing on the relative demand for low skilled labour remains ambiguous: nine out of 28 estimated coefficients are statistically significant, of which only five have the expected sign.

Falk and Koebel (2000) use a similar approach, again applying a fairly wide definition of international outsourcing. Using a Box Cox cost function, which nests the normalised quadratic as well as the translog functional form, they estimate elasticities of substitution between the variable input factors: high-, medium- and low skilled labour as well as imported intermediate materials, domestic non-energy intermediate materials, energy and intermediate services. However their findings suggest that neither imported material inputs nor intermediate services substitute for unskilled labour. In a second step Falk and Koebel (2000) compare their results with those of Feenstra and Hanson (1999), applying a similar translog cost function. Again outsourcing is found to be statistically insignificant for the cost share of unskilled labour.

In the following section a somewhat different empirical model is developed. The model captures the impact of narrowly defined international outsourcing by including the share of imported intermediate inputs as a shift parameter. To the best knowledge of the author, this is the first empirical analysis of the impact of international outsourcing in German manufacturing during the 1990s. 


\section{The Empirical Model}

The starting point for the econometric model is an arbitrary production function for each industry i. If firms are profit maximizing and if isoquants of the production function are convex and returns to scale constant, there exists a dual variable unit cost function for each industry:

$$
c v_{i}=c v\left(W_{i}^{H S}, W_{i}^{L S}, \frac{K_{i}}{Y_{i}}, O u t s_{i}, T_{i}\right)
$$

with $Y_{i}$ denoting output of industry i,

$W_{i}^{H S}$ and $W_{i}^{L S}$ representing the respective wage rates for high- and low-skilled labour,

$\frac{K_{i}}{Y_{i}}$ the quasi fixed capital input expressed as capital intensity,

Outs $_{i}$ the share of imported intermediates as defined in section II and

$T_{i}$ technology.

Both Outs $_{i}$ and $T_{i}$ are parameters that represent a change in the production technology either due to international outsourcing or due to technological progress. Assuming that capital is quasi fixed takes account of the fact that it may differ from its long-run equilibrium, implicitly incorporating adjustment costs.

The unit cost function can be approximated by a general translog function with variable and quasi fixed input factors that was introduced by Brown and Christensen (1981). In order to reduce complexity, the industry subscripts are temporarily dropped.

$$
\begin{aligned}
\ln c v= & \alpha_{0}+\beta_{H S} \ln W^{H S}+\beta_{L S} \ln W^{L S} \\
& +1 / 2 \gamma_{H S L S} \ln W^{H S} \ln W^{L S}+1 / 2 \gamma_{L S H S} \ln W^{L S} \ln W^{H S} \\
& +1 / 2 \gamma_{H S H S} \ln W^{H S} \ln W^{H S}+1 / 2 \gamma_{L S L S} \ln W^{L S} \ln W^{L S} \\
& +\delta_{K} \ln \frac{K}{Y}+1 / 2 \delta_{K K} \ln \frac{K}{Y} \ln \frac{K}{Y} \\
& +\varphi_{K L S} \ln \frac{K}{Y} \ln W^{L S}+\varphi_{K H S} \ln \frac{K}{Y} \ln W^{H S} \\
& +\eta_{T} T+1 / 2 \eta_{T T} T^{2}+\eta_{K T} T \ln \frac{K}{Y} \\
& +\eta_{L S T} T \ln W^{L S}+\eta_{H S T} T \ln W^{H S} \\
& +\phi_{O} \text { Outs }+1 / 2 \phi_{O O} \text { Outs }{ }^{2}+\phi_{K O} \text { Outs } \ln \frac{K}{Y} \\
& +\phi_{L S I O} \text { Outs } \ln W^{L S}+\phi_{H S O} \text { Outs } \ln W^{H S}
\end{aligned}
$$

In order to impose symmetry and homogenity on the cost function, the following 
parameter restrictions are required:

$$
\begin{aligned}
& \gamma_{H S L S}=\gamma_{L S H S} \\
& \beta_{H S}+\beta_{L S}=1 \\
& \gamma_{H S H S}+\gamma_{H S L S}=\gamma_{L S L S}+\gamma_{L S H S}=0 \\
& \varphi_{K H S}+\varphi_{K L S}=0 \\
& \eta_{H S T}+\eta_{L S T}=0
\end{aligned}
$$

Differentiation of the variable cost function with respect to prices of the variable factors gives the respective factor demand equation. Since the cost function is in logarithmic form, differentiation yields the factor's share in total variable costs:

$$
\begin{gathered}
\frac{\partial \ln C V}{\partial \ln W^{H S}}=\frac{W^{H S}}{C V} \times \frac{\partial C V}{\partial W^{H S}}=\frac{W^{H S} L^{H S}}{C V}=S^{H S} \\
\frac{\partial \ln C V}{\partial \ln W^{L S}}=\frac{W^{L S}}{C V} \times \frac{\partial C V}{\partial W^{L S}}=\frac{W^{L S} L^{L S}}{C V}=S^{L S}
\end{gathered}
$$

where $S^{H S}$ and $S^{L S}$ denote the cost share of high- and low-skilled labour in variable costs. Since high-skilled and low-skilled labour are the only variable inputs, both factor share equations have to add up to one and only one of them is linearly independent. Equation (10) can be written out more explicitly with industry again being indexed with i:

$$
\begin{aligned}
S_{i}^{L S}= & \beta_{L S}+1 / 2 \gamma_{L S H S} \ln W_{i}^{H S}+1 / 2 \gamma_{H S L S} \ln W_{i}^{H S} \\
& +\gamma_{L S L S} \ln W_{i}^{L S} \\
& +\varphi_{K L S} \ln \frac{K_{i}}{Y_{i}}+\phi_{O L S} \text { Outs }_{i}+\eta_{T L S} T_{i}
\end{aligned}
$$

The cost share can be understood as a composite expression of the relative demand for low-skilled labour that reflects not only relative employment but also relative factor prices. With the inclusion of the imposed symmetry and homogeneity restrictions, the equation can be further simplified. The result is a linear equation expressed in the logarithmic of the relative wage for low-skilled labour, output, the quasi fixed input factor capital, as well as the non-logarithmic technological shift parameters for each industry. Adding a time dimension and a stochastic error term $u_{i}$ with $E\left(u_{i}\right)=0$ and $\operatorname{Var}\left(u_{i}\right)=\sigma^{2}$ yields a fully specified econometric model: 


$$
\begin{aligned}
S_{i}^{L S}= & \beta_{L S}+\theta \ln \left(W_{i t}^{H S} / W_{i t}^{L S}\right) \\
& +\varphi_{K L S} \ln \frac{K_{i t}}{Y_{i t}}+\phi_{O L S} \text { Outs }_{i t}+\eta_{R D L S} T_{i t}+u_{i t}
\end{aligned}
$$

In imposing the restriction that the coefficients of the independent variables are equal across industries, the estimation can be pooled, hence utilizing time and cross section variation.

As mentioned previously, the dependent variable is a composite measure of the demand for low-skilled labour that reflects relative employment and relative wages. The relative wage variable is therefore by definition correlated with the dependent variable. However including the relative wage variable is appropriate as it can control for some of the variation in the composite dependent variable leaving the remaining variation in relative employment to be explained by the other exogenous variables. It does seem questionable, however, whether or not the relative wage variable $\ln \left(W_{i}^{H S} / W_{i}^{L S}\right)$ is indeed exogenous. If industry wages and the relative demand for low-skilled labour are simultaneously determined, which cannot be ruled out even with high wage coordination across German manufacturing industries, estimation of the model would deliver biased coefficients. The relative wage variable is constructed from the total wage cost and the total number of employees per industry and skill group. Hence, it denotes by definition the ex post average relative wage that was realised in period t. Due to the retrospective character of the variable it can therefore be argued that firms in the empirical model minimise costs subject to the relative wage that was prevalent in the previous period. Therefore the lagged value of the relative wage is included in the regression. As a result the potential endogeneity bias is avoided.

The technological shift over time is approximated by the share of research and development investment in total output. Since data on research and development investment at the industry level is notoriously incomplete and not very reliable, aggregate research and development investment of all manufacturing industries is used as a proxy instead. This assumes a common technological drift across all industries which may not be too problematic since technological diffusion is arguably very high within a country. ${ }^{8}$ However using a technology parameter that varies only

${ }^{8}$ This method is definitely superior to the use of a common time trend which could pick up all sorts of changes over time. 
over time but not across panel groups could give rise to distorted standard errors, as described by Moulton (1990).

Furthermore it could be argued that due to the different sizes of the industries, the stochastic error term is likely to be heteroscedastic. Again this would imply distorted standard errors. Both problems are tackled by adjusting the standard errors for contemporaneous correlation and heteroscedasticity applying the estimator of Beck and Katz (1995) which gives more conservative standard errors than the FGLS estimator in the context of a small number of panel groups and time periods. ${ }^{9}$

The coefficient of the output variable should take on a positive sign, because increases in production are associated with an increased input of production labour, among whom low-skilled workers are more predominant. The coefficient of capital is expected to have a negative sign, as it is well established that, while labour and capital are in general substitutes, capital is more readily substituted for lowskilled than for high-skilled labour [see, for instance, Griliches (1969)]. As a result, the cost share of low-skilled labour should decrease as capital increases. Following the model of Feenstra and Hanson (1996) international outsourcing is expected to have a negative impact on the relative demand for low-skilled labour. Hence, the coefficient of imported intermediate inputs is expected to take on a negative sign. Technological progress is presumably biased against unskilled labour [compare Berman et al. (1994)], hence the coefficient should have a negative sign.

\section{Empirical Results}

The results of the regression are shown in table 3. In the first specification (column a) the coefficients have the expected signs. With the exception of the capital variable, all coefficients are statistically significant. The coefficient of the outsourcing parameter is also negative and statistically significant. Furthermore technological progress seems to be biased against low-skilled labour as the statistically significant negative coefficient indicates. Capital is not found to have a negative impact on the relative demand for low-skilled labour. In a second specification (column b) capital is differentiated into equipment ${ }^{10}$ and plant. ${ }^{11}$ The coefficients of the outsourcing parameter and of research and development investment are statistically significant

\footnotetext{
${ }^{9}$ Applying the FGLS estimator instead does not change the outcome of the regression in any significant manner, whatsoever.

${ }^{10}$ Including machinery and immaterial goods such as software.

${ }^{11}$ Including buildings and land.
} 
and have the expected sign. Regarding capital, only equipment is low-skilled labour saving, while plant is positively related to low-skilled labour. This is in line with the findings of Berman et al. (1994) for the US.

In a third model specification, the relative wage of low-skilled workers is excluded from the regression following the approach of Berman et al. (1994), Feenstra and Hanson (1996), Feenstra and Hanson (1999), Anderton and Brenton (1999) and others. Again all coefficients are statistically significant an have the expected sign, however the coefficients are biased due to the omitted variable.

Thus independent of the specification there is strong evidence for a negative impact of international outsourcing on the relative demand for low-skilled workers.

Based on the point estimates, the economic relevance of international outsourcing can be accessed in more detail. Between 1991 and 2000 international outsourcing of total manufacturing ${ }^{12}$ increased by 9.74 percentage points. In the same period the low-skilled cost share in the total wage bill of manufacturing decreased by 4.06 percentage points. Of this, international outsourcing can explain ceteris paribus between $19 \%$ and $24 \%$, as the coefficients of the outsourcing parameter in the three specifications (a: -0.078 , b: -0.102 , c: -0.093) suggest.

However skill-biased technological change is at least equally important for the relative demand for low-skilled workers. Of the 4.06 percentage point decline in the cost share, ceteris paribus approximately $25 \%$ can be explained by the 3.22 percentage point increase in the share of research and development investment, as the coefficients (a: -3.192 , b: -3.032 c: -3.098 ) indicate.

\section{Conclusion}

The empirical analysis showed that international outsourcing is indeed an important explanatory factor for the observed decline in relative demand for low-skilled labour in German manufacturing. Controlling for the adverse demand effects of skill-biased technological change and capital upgrading, international outsourcing can explain up to $24 \%$ of the decrease in the low-skilled cost share during the 1990s. With relative wages that were close to stable, the reduced demand for low-skilled workers had to be mainly met by decreasing relative employment of the low-skilled. In the light of growing integration in world markets, for instance due to the eastern enlargement of the EU, international outsourcing is likely to lead to further negative

\footnotetext{
${ }^{12}$ Excluding: printing, publishing; coke, petroleum products, nuclear fuel and recycling.
} 
demand shifts away from less skilled workers in the future. Under the current regime of nearly inflexible relative wages, low-skilled workers are therefore increasingly likely to be permanently excluded from the labour market. 


\section{References}

Anderton, Bob and Paul Brenton, "Outsourcing and Low-Skilled Workers in the UK," Bulletin of Economic Research, 1999, 51 (4), 267-285.

Beck, Nathanial and Jonathan N. Katz, "What to do (and not to do) with time-series cross-section data," American Political Science Review, 1995, 89 (3), 634-647.

Berman, Eli, John Bound, and Stephen Machin, "Implications of Skill-Biased Technological Change: International Evidence," Quarterly Journal of Economics, 1998, 113 (4), 1245-1280.

- , - , and Zvi Griliches, "Changes in the demand for skilled labor within U.S. manufacturing: evidence from the annual survey of manufacturing," Quarterly Journal of Economics, 1994, 109 (2), 367-397.

Brown, Randall S. and Lauritis R. Christensen, "Estimating Elasticities of Substitution in a Model of Partial Static Equilibrium: An Apllication to U.S. Agriculture, 1947-1974," in E. R. Berndt and B. C. Field, eds., Modeling and Measuring Natural Resource Substitution, Cambridge, Massechusetts: MIT Press, 1981, pp. 209-229.

Campa, José and Linda S. Goldberg, "The evolving external orientation of manufacturing industries: evidence from four countries," Working Paper 5919, National Bureau of Economic Research 1997.

Christensen, Björn and Axel Schimmelpfennig, "Arbeitslosigkeit, Qualifikation und Lohnstruktur in Westdeutschland," Die Weltwirtschaft, 1998, 2, 177-186.

Diehl, Markus, "The Impact of International Outsourcing on the Skill Structure of Employment: Empirical Evidence from German Manufacturing Industries," Kiel Working Paper 946, Institut für Weltwirtschaft 1999.

Falk, Martin and Bertrand Koebel, "Outsourcing of Services, Imported Materials and the Demand for Heterogeneous Labour: An Application of a Generalised Box-Cox Function," Discusssion Paper 00-51, Zentrum für Europäische Wirtschaftsforschung 2000.

Feenstra, Robert C. and Gordon H. Hanson, "Foreign Direct 
Investment, Outsourcing and Relative Wages," in Robert C. Feenstra, Gene M. Grossman, and D. A. Irwin, eds., The Political Economy of Trade Policy: Papers in Honor of Jagdish Bhagwati, Cambridge, Massechusetts: MIT Press, 1996, pp. 89-127.

- and -, "The impact of outsourcing an dhigh-technology capital on wages: estimates for the United States, 1979-1990," Quarterly Journal of Economics, 1999, 114 (3), 907-940.

Fitzenberger, Bernd, "Wages and Employment Across Skill Groups," Economic Studies 6, Zentrum für Europäische Wirtschaftsforschung 1999.

- et al., "Testing for Uniform Wage Trends in West-Germany: A Cohort Analysis Using Quantile Regressions for Censored Data," Empirical Economics, 2001, 26 (1), 41-86.

Griliches, Zvi, "Capital Skill Complementarity," The Review of Economics and Statistics, 1969, 51, 465-468.

Hummels, David, Jun Ishii, and Kei-Mu Yi, "The nature and growth of vertical specialization in worlde trade," Journal of International Economics, 2001, 54, 75-96.

Moulton, Brent R., "An illustration of the pitfall in estimating the effects of aggregate variables in micro units," The Review of Economics and Statistics, 1990, (72), 334-338.

Reinberg, Alexander and Markus Hummel, "Qualifikationsspezifische Arbeitslosenquoten - reale Entwicklung oder statistisches Artefakt?," Werkstattbericht 4, Institut fr Arbeitsmarkt und Berufsforschung 2002.

Schimmelpfennig, Axel, "Skill-Biased Technical Change vs.Structural Change," Working Paper 868, Institut für Weltwirtschaft, Kiel Working Paper 1998.

Yeats, Alexander, "Just how big is global production sharing?," Policy Research Working Paper 1871, World Bank 1998. 


\section{A Data}

The empirical analysis is based on aggregated manufacturing industry data for the period 1991-2000, following the NACE Rev. 1.1 classification. Unfortunately, systematic changes in the industry classification prevent the usage of longer time series before 1991. Data is available for 23 manufacturing industries with nine observations over time. However the industries publishing and printing; oil refining and nuclear fuel; and recycling are excluded from the analysis. This yields a total number of 180 observations.

Data on the average wage, as well as on the total wage payments at a sectoral level, are available only for the broad groups of production and nonproduction workers. High-skilled workers are assumed to be non-production workers. This can be justified by the fact that the share of higher skill levels in non-production labour is higher than that in production labour. Data can be obtained from the online time series service of the German Federal Statistical Office (www.statistik-bund.de).

Data on the used capital at 1995 prices and nominal production values can also be obtained from this source.

The values of domestic and imported intermediate inputs as well as the industries' production values are derived from the annual German input-output tables (Federal Statistical Office, Fachserie 18, Reihe 2). The value of domestic and imported intermediate inputs and the production value is adjusted to the prices of 1995 using the aggregate producer price index for manufacturing goods (Federal Statistical Office, Fachserie 17, Reihe 21) and the price index for imported manufacturing goods (Federal Statistical Office, Fachserie 17, Reihe 8).

Data on research and development investment is available from the Stifterverband für die Deutsche Wissenschaft, the same institution that provides the raw German data for the ANBERD data base. 
Table 1: Average yearly employment growth for different skill groups*

\begin{tabular}{ccccc} 
& Overall & Medium-Skilled & High-Skilled & Low Skilled \\
$1975-2000$ & $0.58 \%$ & $1.32 \%$ & $4.02 \%$ & $-2.67 \%$ \\
$1975-1990$ & $0.73 \%$ & $2.10 \%$ & $4.32 \%$ & $-3.55 \%$ \\
$1991-2000$ & $0.36 \%$ & $0.15 \%$ & $3.56 \%$ & $-1.34 \%$ \\
\hline
\end{tabular}

* Only Western Germany and Berlin-West

Source: Reinberg and Hummel (2002), authors' calculations 
Table 2: Share of imported intermediate inputs* between 1991 and 2000 in \%

\begin{tabular}{clccc} 
NACE & Industry & 1991 & 2000 & Change in \%-points \\
$\mathrm{D}$ & Manufacturing** & 30.60 & 40.34 & 9.74 \\
15 & Food products, beverages & 18.69 & 22.51 & 3.82 \\
16 & Tobacco products & 1.22 & 18.34 & 17.12 \\
17 & Textiles & 18.84 & 43.15 & 24.32 \\
18 & Wearing Apparel & 62.11 & 93.38 & 31.28 \\
19 & Leather & 48.72 & 69.99 & 21.28 \\
20 & Wood, Products of Wood & 16.50 & 17.41 & 0.90 \\
21 & Pulp, Paper, paper products & 68.39 & 77.04 & 8.65 \\
24 & Chemicals & 43.09 & 63.29 & 20.19 \\
25 & Rubber and Plastic Products & 6.87 & 11.18 & 4.31 \\
26 & Other Non-Metallic Mineral Products & 19.18 & 20.54 & 1.36 \\
27 & Basic Metals & 42.70 & 60.50 & 17.80 \\
28 & Fabricated Metal Products & 6.23 & 9.05 & 2.83 \\
29 & Machinery and Equipments n.e.c & 26.65 & 32.08 & 5.42 \\
30 & Office Machinery and Computers & 42.39 & 86.29 & 43.90 \\
31 & Electrical Machinery and Apparatus & 14.88 & 22.24 & 7.36 \\
32 & Radio, TV, Communication Equipment & 54.17 & 62.69 & 8.53 \\
33 & Medical, Precision, Optical Instruments, Clocks & 34.84 & 50.47 & 15.63 \\
34 & Motor Vehicles, Trailers & 34.04 & 32.49 & -1.55 \\
35 & Other Transport Equipment & 97.37 & 99.57 & 2.21 \\
36 & Furniture, Manufacturing n.e.c. & 57.56 & 74.26 & 16.70 \\
\hline & & & \\
\hline
\end{tabular}

*as defined in equation 1

** excluding NACE 22,23,37 
Table 3: PCSE regression results

\begin{tabular}{lllllll}
\hline & \multicolumn{2}{c}{$\mathrm{a}$} & \multicolumn{2}{c}{$\mathrm{b}$} & \multicolumn{1}{c}{$\mathrm{c}$} \\
$\ln (\mathrm{K} / \mathrm{Y})$ & -0.020 & $(-1.13)$ & & & & \\
$\ln (\mathrm{Equ} / \mathrm{Y})$ & & & -0.075 & $(-5.23)^{* * *}$ & -0.061 & $(-2.69)^{* * *}$ \\
$\ln (\mathrm{Plant} / \mathrm{Y})$ & & & 0.053 & $(4.07)^{* * *}$ & 0.039 & $(1.82)^{*}$ \\
$\mathrm{RD} / \mathrm{Y}$ & -3.192 & $(-1.64)^{*}$ & -3.032 & $(-1.68)^{*}$ & -3.098 & $(-1.79)^{*}$ \\
$\ln \left(W^{L S} / W^{H S}\right)_{l a g}$ & 0.200 & $(2.19)^{* *}$ & 0.379 & $(3.55)^{* * *}$ & & \\
Outs & -0.078 & $(-3.05)^{* * *}$ & -0.102 & $(-3.98)^{* * *}$ & -0.093 & $(-3.36)^{* * *}$ \\
$\operatorname{constant}$ & 0.466 & $(1.72)^{*}$ & 0.549 & $(2.14)^{* *}$ & 0.345 & $(1.31)$ \\
& & & & & & \\
$R^{2}$ & & 89.44 & & 89.11 & & 87.82 \\
\hline
\end{tabular}

180 Observations in a and b, 200 observations in c, common $\mathrm{AR}(1)$ correlation t-statistics in parentheses $*$ significant at $10 \%,{ }^{* *}$ at $5 \%,{ }^{* * *}$ at $1 \%$ 